University of Wollongong

Research Online

Faculty of Engineering and Information

Faculty of Engineering and Information

Sciences - Papers: Part A

Sciences

$1-1-2013$

\title{
Effect of confining pressure and frequency on the deformation of ballast
}

Pramod Kumar Thakur

University of Wollongong, pkt958@uow.edu.au

Jayan Sylaja Vinod

University of Wollongong, vinod@uow.edu.au

Buddhima Indraratna

University of Wollongong, indra@uow.edu.au

Follow this and additional works at: https://ro.uow.edu.au/eispapers

Part of the Engineering Commons, and the Science and Technology Studies Commons

Research Online is the open access institutional repository for the University of Wollongong. For further information contact the UOW Library: research-pubs@uow.edu.au 


\title{
Effect of confining pressure and frequency on the deformation of ballast
}

\begin{abstract}
Increasing the speed and frequency of trains with the same static axle weight imparts higher dynamic axle loads more frequently. When this occurs on existing track which has not been designed for such loading there can be increased rates of ballast degradation, characterised by unacceptable deformation and lateral spread, leading to more frequent requirements for track maintenance. Recent studies carried out at the University of Wollongong highlighted that confining pressure and frequency have a significant influence on the permanent deformation and degradation of ballast. However, confinement required to keep the deformation and degradation of the ballasted track to an acceptable limit will depend on the train speed (frequency). In this context, a series of cyclic triaxial tests was conducted on latite basalt samples having an initial confining pressure of $120 \mathrm{kPa}$. After every $25000 \mathrm{cycles}$, the confining pressure was decreased in steps to simulate the drop of confining pressure during heavy traffic. This test procedure was adopted to replicate the influence of train speed on the stability of ballast. Test results indicated that both the frequency and confining pressure have a significant influence on the permanent deformation of ballast. Resilient modulus is found to increase with an increase in confining pressure and number of cycles, but to decrease with increasing frequency. The results also showed that the ballast layer requires a minimum level of confinement for preventing an excessive amount of track deformation. An empirical equation is formulated to determine the required confining pressure and resilient modulus of the ballast layer for an allowable limit of track deformation at a given train speed.
\end{abstract}

\section{Keywords}

frequency, confining, pressure, effect, ballast, deformation

Disciplines

Engineering | Science and Technology Studies

\section{Publication Details}

Thakur, P. K., Vinod, J. S. \& Indraratna, B. (2013). Effect of confining pressure and frequency on the deformation of ballast. Geotechnique: international journal of soil mechanics, 63 (9), 786-790. 


\title{
TECHNICAL NOTE
}

\section{Effect of confining pressure and frequency on the deformation of ballast}

\author{
P. K. THAKUR*, J. S. VINOD† and B. INDRARATNA
}

\begin{abstract}
Increasing the speed and frequency of trains with the same static axle weight imparts higher dynamic axle loads more frequently. When this occurs on existing track which has not been designed for such loading there can be increased rates of ballast degradation, characterised by unacceptable deformation and lateral spread, leading to more frequent requirements for track maintenance. Recent studies carried out at the University of Wollongong highlighted that confining pressure and frequency have a significant influence on the permanent deformation and degradation of ballast. However, confinement required to keep the deformation and degradation of the ballasted track to an acceptable limit will depend on the train speed (frequency). In this context, a series of cyclic triaxial tests was conducted on latite basalt samples having an initial confining pressure of $120 \mathrm{kPa}$. After every 25000 cycles, the confining pressure was decreased in steps to simulate the drop of confining pressure during heavy traffic. This test procedure was adopted to replicate the influence of train speed on the stability of ballast. Test results indicated that both the frequency and confining pressure have a significant influence on the permanent deformation of ballast. Resilient modulus is found to increase with an increase in confining pressure and number of cycles, but to decrease with increasing frequency. The results also showed that the ballast layer requires a minimum level of confinement for preventing an excessive amount of track deformation. An empirical equation is formulated to determine the required confining pressure and resilient modulus of the ballast layer for an allowable limit of track deformation at a given train speed.
\end{abstract}

KEYWORDS: deformation; laboratory tests; repeated loading

\section{INTRODUCTION}

The increased demand for high-speed trains is contributing to higher loads on the rail ballast and can cause excessive deformation and degradation. Undesired deformation and degradation of ballast affects the safety of the rail operation and ride comfort. Ballast is one of the major components of the rail track responsible for transferring loads to sub-strata, absorbing noise, draining water and so on (Selig \& Waters, 1994). Moreover, owing to the increased traffic loads, the initial confining pressure of the ballast can decrease and can exhibit large vertical deformation and lateral spread. Therefore, these tracks require frequent maintenance for the safe operation of passenger and freight trains. Recently, Indraratna et al. $(2005,2010)$ and Lackenby et al. (2007) conducted laboratory experiments to understand the effect of confining pressure and frequency on the permanent deformation and degradation of ballast. Indraratna et al. (2005) highlighted that during cyclic loading, the pattern of particle breakage could be characterised by three distinct degradation zones

\section{(a) dilatant unstable degradation zone (DUDZ)}

Manuscript received 26 January 2012; revised manuscript accepted 21 June 2012. Published online ahead of print 20 September 2012.

Discussion on this paper closes on 1 December 2013, for further details see $\mathrm{p}$. ii.

* Snowy Mountain Engineering Corporation, Australia Pty Ltd; formerly, School of Civil, Mining and Environmental Engineering, University of Wollongong, NSW, Australia.

$\uparrow$ School of Civil, Mining and Environmental Engineering, University of Wollongong, NSW, Australia.

$\$$ Centre for Geomechanics and Railway Engineering, Faculty of Engineering, University of Wollongong, NSW, Australia. (b) optimum degradation zone (ODZ)

(c) compressive stable degradation zone (CSDZ).

These zones are defined by the level of effective confining pressure $\left(\sigma_{3}^{\prime}\right)$ acting on the specimen and also depend on the level of the applied maximum deviator stress $q_{\max }$. Lackenby et al. (2007) and Indraratna et al. (2010) revealed that the permanent deformation and degradation of railway ballast under cyclic loading is influenced by confining pressure and frequency. Lackenby et al. (2007) also investigated the densification and particle degradation response of railway ballast under cyclic loading; they determined that the extent of densification and particle breakage was significantly affected by the confining pressure. However, these conclusions were based on large-scale triaxial tests at constant frequency of $20 \mathrm{~Hz}$ even though the confining pressures were changed from 15 to $240 \mathrm{kPa}$. Therefore, this study could not capture the role of train speed (directly proportional to frequency) on the permanent deformation of ballast. Indraratna et al. (2009) concluded that the particle breakage has a significant influence on the resilient modulus of the railway ballast. However, none of these studies was able to capture the effect of decreasing confining pressure on the permanent deformation of ballast due to the increasing train speed. Therefore, the current paper presents investigations into the effect of varying confining pressure and frequency on the permanent deformation and resilient behaviour of ballast. A series of cyclic triaxial tests was conducted on latite basalt samples with an initial confining pressure of $120 \mathrm{kPa}$. After every 25000 cycles, the confining pressure was decreased in steps and the frequency was changed from 10 to $40 \mathrm{~Hz}$ to represent different train speeds. This test procedure was adopted to replicate the influence of train speed on the 
stability of ballast at various levels of ballast confining pressure that replicate realistic track conditions

\section{LABORATORY INVESTIGATION}

Laboratory tests were conducted using the large-scale cyclic triaxial apparatus, designed and built at the University of Wollongong. Specimens' dimensions were $300 \mathrm{~mm}$ in diameter and $600 \mathrm{~mm}$ high. Fig. 1 shows the particle size distribution (PSD) curve of ballast adopted for this study, which is representative of the current practice in Australia (Standards Australia, 1996). The ballast particles were first washed by water jet, so that they were free from dust, and then dried in the sun. They were then sieved through a set of sieves $(53 \mathrm{~mm}, 45 \mathrm{~mm}, 37.5 \mathrm{~mm}, 31.5 \mathrm{~mm}, 26.5 \mathrm{~mm}$ and $19 \mathrm{~mm}$ ) and stored separately. Particles from each sieve size were weighed and then mixed properly. The mixed particles were placed in four different layers into a $5 \mathrm{~mm}$ thick neoprene rubber membrane and compacted using a vibrator to a representative field density of $1530 \mathrm{~kg} / \mathrm{m}^{3}$. A membrane correction of $15 \mathrm{kPa}$ to a cyclic deviatoric stress $\left(q_{\mathrm{cyc}}\right)$ was applied for the $5 \mathrm{~mm}$ thick Neoprene rubber membrane (ASTM, 2002). A rubber pad was used on top of the ballast particles before placing a vibrator, in order to minimise breakage during compaction. The compaction was facilitated by a split cylindrical mould, which was removed before the specimen was placed within the cell pressure chamber. To study the effect of decrease in confining pressures with increase in train speed, the sample was given an initial confining pressure of $120 \mathrm{kPa}$ (about 3-4 times the normal confining pressure that exists in typical tracks). The sample was left overnight for consolidation before applying the cyclic load. Each sample was loaded statically first at a rate of $1 \mathrm{~mm} / \mathrm{s}$ to a stress equal to the average of the minimum and maximum cyclic deviatoric stress. Cyclic loading was then applied up to 25000 cycles at a confining pressure of $120 \mathrm{kPa}$ and a frequency of $10 \mathrm{~Hz}$. Subsequently, the confining pressure was reduced gradually to $60 \mathrm{kPa}$ and another 25000 cycles were applied. Cyclic loading was continued, further reducing the confining pressure to $30 \mathrm{kPa}$ and $15 \mathrm{kPa}$. It should be noted that 25000 cycles of loading was maintained for each confining pressure. This was based on the earlier findings that the permanent deformations would remain constant around 10000-25000 cycles, irrespective of the applied confining pressure (Lackenby et al., 2007). In total, cyclic loading was continued for 100000 cycles or until the axial strain exceeded $25 \%$. This whole procedure was repeated for $20 \mathrm{~Hz}$ and $40 \mathrm{~Hz}$ frequencies to replicate the effect of increasing train speed. Details of these tests are summarised in Table 1.

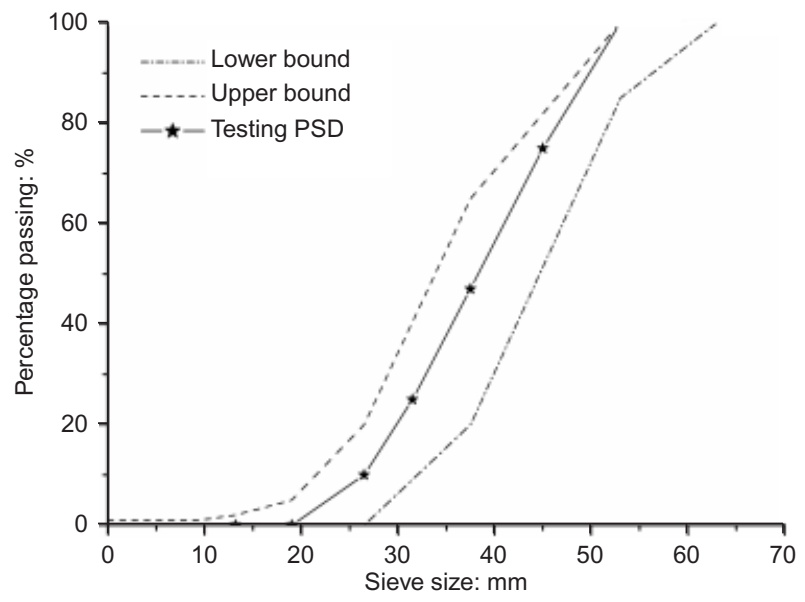

Fig. 1. Initial particle size distribution of ballast sample
Table 1. Summary of cyclic triaxial tests

\begin{tabular}{l|c|c|c}
\hline $\begin{array}{l}\text { Frequency, } f: \\
\mathrm{Hz}\end{array}$ & $\begin{array}{c}\text { Confining pressure, } \\
\sigma_{3}^{\prime}: \mathrm{kPa}\end{array}$ & $\begin{array}{c}\sigma_{\mathrm{d}}: \mathrm{kPa} \\
\text { (Esveld, 2001) }\end{array}$ & $\begin{array}{c}\text { Number of } \\
\text { cycles, } N\end{array}$ \\
\hline 10 & $15,30,60,120$ & 374 & 100000 \\
20 & $15,30,60,120$ & 428 & 100000 \\
$40^{*}$ & $15,30,60,120$ & 536 & 75000 \\
\hline
\end{tabular}

${ }^{*} \varepsilon_{\mathrm{a}}>25 \%$ after 75000 cycles.

A typical harmonic cyclic load (a sinusoidal waveform) was used during the testing programme. Detailed explanations of the testing equipment and experimental procedures can be found elsewhere (Indraratna et al., 2005, 2010; Lackenby et al., 2007). The minimum cyclic deviatoric stress $\left(q_{\text {min }}\right)$ was kept at $45 \mathrm{kPa}$ (Lackenby et al., 2007) to take into account the weight of sleeper and rail. Shenton (1975) stated that higher train speeds may increase the dynamic forces and impart greater stresses to the ballast. Kempfert \& Hu (1999) carried out in situ measurements of dynamic forces in the track induced by speeds up to $400 \mathrm{~km} / \mathrm{h}$ and highlighted that the dynamic stress increased significantly as the speed increased from $150 \mathrm{~km} / \mathrm{h}$ to $300 \mathrm{~km} / \mathrm{h}$. Therefore, cyclic deviatoric stresses $\left(q_{\text {cyc }}\right)$ were calculated following Esveld (2001) for respective train speeds (frequency); these are presented in Table 1. Details of the Esveld's method to calculate contact pressure on ballast is given in the Appendix.

\section{EXPERIMENTAL RESULTS AND DISCUSSION \\ Permanent deformation behaviour}

Figure 2(a) illustrates the axial strain $\left(\varepsilon_{\mathrm{a}}\right)$ at various frequencies $(f)$ and the effective confining pressure $\left(\sigma_{3}^{\prime}\right)$ with number of cycles $(N)$. It is observed that $\varepsilon_{\mathrm{a}}$ increases with the increase in $f$ and decrease in $\sigma_{3}^{\prime}$. Also, it increases with increase in $N$. $\varepsilon_{\mathrm{a}}$ increases rapidly in the initial cycles and stabilises after a few thousand cycles. Lackenby et al. (2007) reported that the $\varepsilon_{\mathrm{a}}$ stabilises or shakedowns (insignificant rate of increase of $\varepsilon_{\mathrm{a}}$ with $N$ ) at around 10000 cycles. In addition, Fig. 2(a) shows that when $\sigma_{3}^{\prime}$ decreases to $60 \mathrm{kPa}$ from $120 \mathrm{kPa}, \varepsilon_{\mathrm{a}}$ again increases rapidly in the initial few cycles. It stabilises again after application of an additional 10000 cycles at lower frequency range $(f \leqslant 20 \mathrm{~Hz})$. Initial deformation is more rapid with decreasing confining pressure (e.g. initial deformation occurred around four times larger for reduction in $\sigma_{3}^{\prime}$ from $30 \mathrm{kPa}$ to $15 \mathrm{kPa}$, as compared to the change in $\sigma_{3}^{\prime}$ from $120 \mathrm{kPa}$ to $60 \mathrm{kPa}$ ). However, at high frequency such as at $f=40 \mathrm{~Hz}$, when $\sigma_{3}^{\prime}$ decreases from $60 \mathrm{kPa}$ to $30 \mathrm{kPa}$, rapid deformation continued to occur and did not stabilise before reaching failure (i.e. $\varepsilon_{\mathrm{a}}=25 \%$ ). These results clearly indicate the requirement of a threshold value of $\sigma_{3}^{\prime}$ in limiting track deformation. At very low $\sigma_{3}^{\prime}$, for example $15-30 \mathrm{kPa}$, excessive deformation of the track may occur even at low train speeds (i.e. $f \leqslant 20 \mathrm{~Hz}$ ) and the ballast requires $\sigma_{3}^{\prime} \geqslant 60 \mathrm{kPa}$ for operating high-speed trains $(f \geqslant 40 \mathrm{~Hz})$. Such type of ballast behaviour can be attributed to rapid particle rearrangement and breakage at high $f$. $\varepsilon_{\mathrm{a}}$ increases rapidly (at low values of $N$ ) followed by a stabilised state that occurs around an additional load application of 10000 cycles. This can be seen from the results of $f=10$ and $20 \mathrm{~Hz}$ where $\sigma_{3}^{\prime}$ is adequately capable of providing stable $\varepsilon_{\mathrm{a}}$. In case of high $f$, such as $40 \mathrm{~Hz}, \sigma_{3}^{\prime}$ below $60 \mathrm{kPa}$ cannot provide enough support to the sample (Fig. 2(a)) and as a consequence, stable $\varepsilon_{\mathrm{a}}$ is hard to attain. This test results imply that higher confining pressure on tracks catering for higher speeds will be more appropriate, as conventional 


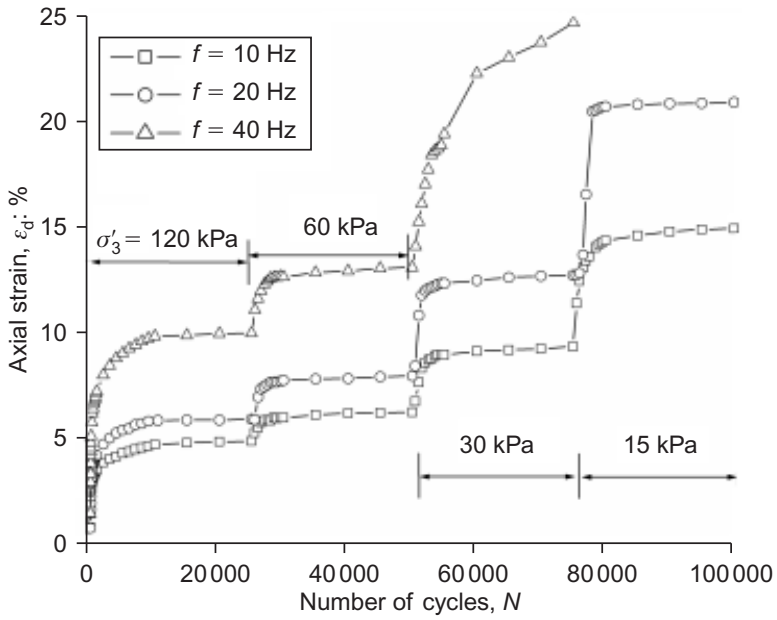

(a)

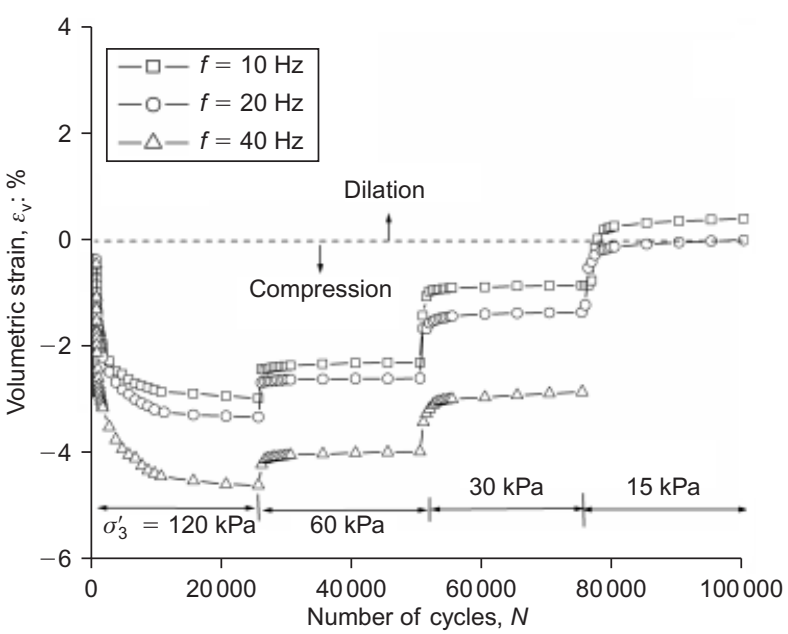

(b)

Fig. 2. Effect of variation of confining pressure $\left(\sigma_{3}^{\prime}\right)$ on (a) axial strain $\left(\varepsilon_{\mathrm{a}}\right)$ and $(\mathrm{b})$ volumetric strain $\left(\varepsilon_{\mathrm{v}}\right)$ at various frequencies $(f)$ with number of cycles $(N)$

Australian tracks rarely have confining pressures exceeding $30 \mathrm{kPa}$ (Lackenby et al., 2007).

Figure 2(b) shows the volumetric strains $\left(\varepsilon_{\mathrm{v}}\right)$ (negative compression) behaviour at various $f$ and $\sigma_{3}^{\prime}$ with $N$. At $\sigma_{3}^{\prime}=120 \mathrm{kPa}, \varepsilon_{\mathrm{v}}$ is compressive for all $f$ and it increases with increase in $f$ and $N$. At all frequencies, when the sample experiences a decrease in confining pressure, it dilates rapidly during the initial 1000 cycles, followed by a stable $\varepsilon_{\mathrm{V}}$.

\section{Resilient behaviour}

Lekarp et al. (2000) reported that the frequency and load duration has little or no significant effect on resilient modulus of granular materials. However, they also mentioned that the resilient modulus may decrease with increase of frequency in undrained conditions. In this study, the effect of $f$ and $\sigma_{3}^{\prime}$ on the resilient modulus $\left(M_{\mathrm{r}}\right)$ was assessed by recording the resilient (recoverable strain) $\varepsilon_{\mathrm{a} \text {,rec }}$ and deviator stress magnitude $q_{\mathrm{cyc}}\left(q_{\max }-q_{\min }\right)$ at various number of cycles $N$ using the following expression

$$
M_{\mathrm{r}}=\frac{q_{\mathrm{cyc}}}{\varepsilon_{\mathrm{a}, \mathrm{rec}}}
$$

Figure 3 illustrates the effect of $f$ and $\sigma_{3}^{\prime}$ on $M_{\mathrm{r}}$ with $N$. For a particular $f$ and $\sigma_{3}^{\prime}$ (such as $10 \mathrm{~Hz}$ and $120 \mathrm{kPa}$ ), $M_{\mathrm{r}}$ initially increased rapidly and became almost constant after

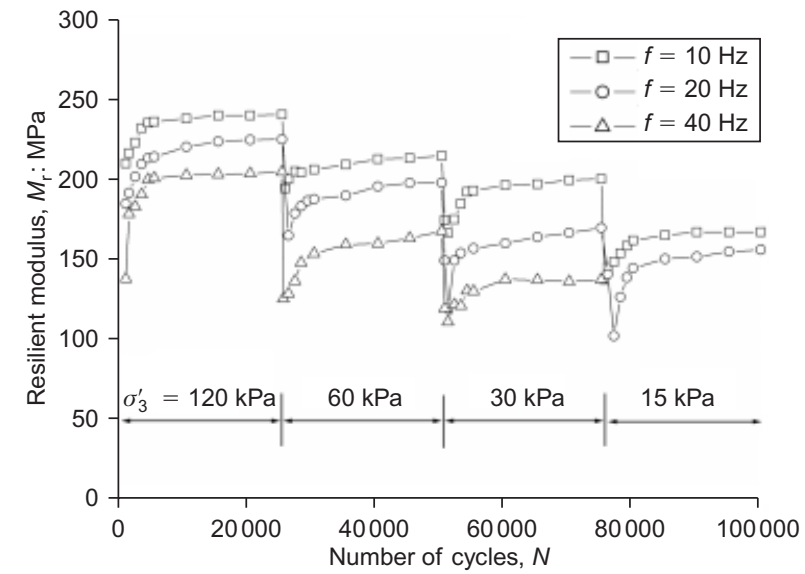

Fig. 3. Effect of variation of confining pressure $\left(\sigma_{3}^{\prime}\right)$ on resilient modulus $\left(M_{\mathrm{r}}\right)$ at various frequencies $(f)$ with number of cycles $(N)$

application of a few thousand cycles (e.g. 10000 cycles). This initial rapid increase in $M_{\mathrm{r}}$ can be attributed to cyclic densification (Figs 2(a) and 2(b)) where ballast particles rearrange and even break in order to achieve a stable configuration. $M_{\mathrm{r}}$ is found to decrease with increase in $f$. However, $M_{\mathrm{r}}$ increases as $\sigma_{3}^{\prime}$ increases.

Selig \& Alva-Hurtado (1982) reported that a reduction in recoverable axial strain $\left(\varepsilon_{\mathrm{a}, \mathrm{rec}}\right)$ with each successive cycle and subsequent increase in $M_{\mathrm{r}}$ can be attributed, at least partly, to densification from cumulative $\varepsilon_{\mathrm{v}}$. This type of behaviour can be seen at all $f$ and $\sigma_{3}^{\prime}$. Fig. 4 presents the variation of final value of resilient modulus $\left(M_{\mathrm{rf}}\right)$ at 25000 cycles for various $f$ plotted against $\sigma_{3}^{\prime}$. It is evident from the figure that $M_{\mathrm{rf}}$ increases linearly with confining pressure. Moreover, $M_{\mathrm{rf}}$ is found to decrease with $f$. An empirical relationship between $M_{\mathrm{rf}}$ and $\sigma_{3}^{\prime}$ is developed and can be expressed as

$$
M_{\mathrm{rf}}=a \sigma_{3}^{\prime}+b
$$

where $a$ and $b$ are material parameters tabulated in Fig. 4 for different values of $f$.

Figure 5 presents the variation of final axial strain, $\left(\varepsilon_{\mathrm{af}}\right)$ and final resilient modulus $\left(M_{\mathrm{rf}}\right)$ for different values of confining pressures and frequencies. It is evident that $\varepsilon_{\mathrm{af}}$ decreases with the increase of $M_{\mathrm{rf}}$ irrespective of $\sigma_{3}^{\prime}$ and $f$. In other words, a higher resilient modulus results in less

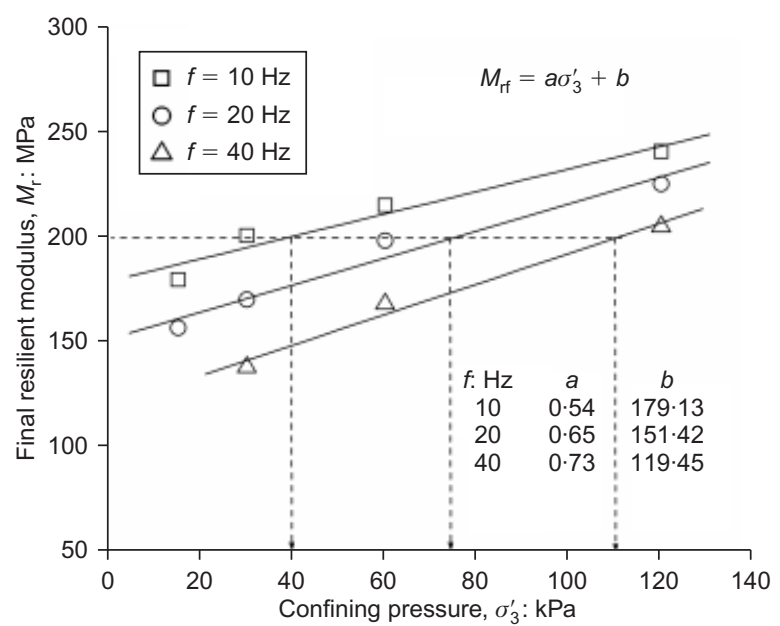

Fig. 4. Trend of variation of final resilient modulus $\left(M_{\mathrm{rf}}\right)$ at various frequencies $(f)$ with confining pressure $\left(\sigma_{3}^{\prime}\right)$ 


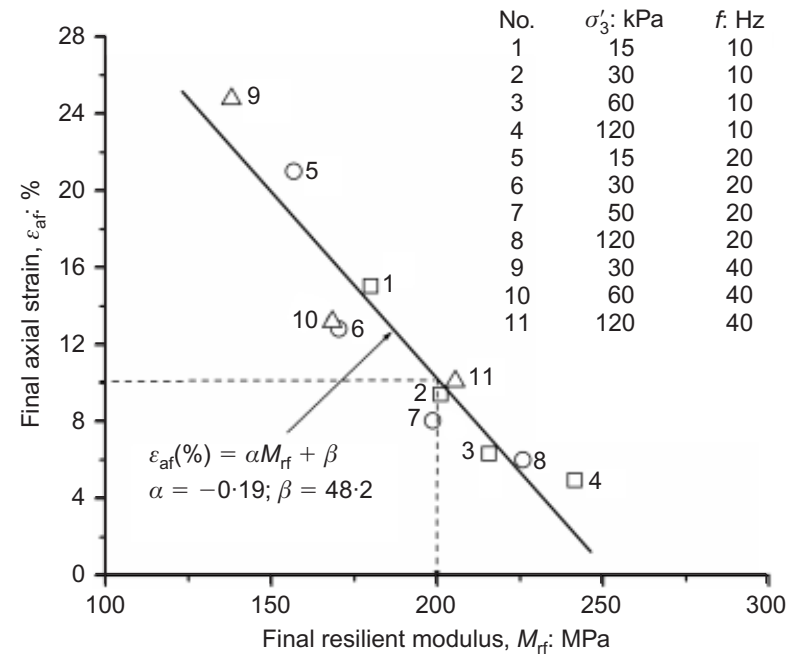

Fig. 5. Relation between final resilient modulus $\left(M_{\mathrm{rf}}\right)$ and final axial strain $\left(\varepsilon_{\mathrm{af}}\right)$

track deformation. Moreover, a unique relationship between $\varepsilon_{\mathrm{af}}$ and $M_{\mathrm{rf}}$ is observed irrespective of $\sigma_{3}^{\prime}$ and $f$, and the relationship can be expressed by

$$
\varepsilon_{\mathrm{af}}(\%)=\alpha M_{\mathrm{rf}}+\beta
$$

where $\alpha$ and $\beta$ are empirical constants determined from laboratory data. In this case, the values of $\alpha$ and $\beta$ are $-0 \cdot 19$ and $48 \cdot 20$ respectively.

Equation (3) can be used to estimate the required resilient modulus of the track for a given track deformation level. For example, for an allowable limit of track deformation, say $10 \%$ of the ballast layer thickness, it is necessary to have the track resilient modulus around $200 \mathrm{MPa}$ (Fig. 5). To achieve $M_{\mathrm{r}}=200 \mathrm{MPa}$, minimum lateral confinement should be around $40 \mathrm{kPa}, 75 \mathrm{kPa}$ and $110 \mathrm{kPa}$ at $10 \mathrm{~Hz}$, $20 \mathrm{~Hz}$ and $40 \mathrm{~Hz}$ frequencies, respectively, as illustrated in Fig. 4. If appropriate $\sigma_{3}^{\prime}$ is not applied to the ballast layer and the train speed increases, the track would be anticipated to suffer severe and undesirable deformation. Equation (3) describes the whole of track deformation, and the current results from the laboratory experiments can be influenced by the sub-ballast and subgrade layer. Moreover, equation (3) is derived under conditions where the major track deformation is contributed to the ballast layer under a given track confinement. Therefore, proper caution should be taken while using equation (3), where track deformation is largely affected by the subgrade soil. Further research/analyses of field data would be helpful to validate the equation for the field cases.

Various methods of increasing track confinement have been discussed by Lackenby et al. (2007), such as preventing lateral ballast flow using containing sheets at the shoulders or geosynthetics at the ballast/capping interface and redesigning the sleeper shape to reduce ballast flow (winged precast concrete sleepers).

\section{CONCLUSIONS}

This paper presents the results of large-scale cyclic triaxial tests conducted on latite basalt at different frequencies and confining pressures. It has been concluded that both frequency and confining pressure have considerable influence on the permanent deformation of ballast. Axial and volumetric strains are found to increase with an increase in frequency and number of cycles. Volumetric strains are observed to increase with the confining pressure irrespective of frequency. Resilient modulus increases with an increase in confining pressure and the number of cycles, but it decreases with increasing frequency. The results confirmed that a minimum lateral confinement was necessary to maintain acceptable deformation. A unique relationship was observed between the final axial strain and resilient modulus, irrespective of the confining pressure and frequency. An empirical relationship is also proposed to estimate the minimum confining pressure and resilient modulus required for a given level of permanent deformation at various frequencies (train speeds). The application of equation (3) is limited to similar track confining pressures and frequencies (speeds) as tested in the laboratory conditions.

\section{ACKNOWLEDGEMENTS}

The authors would like to express their sincere gratitude to the Cooperative Research Council for Railway Engineering and Technologies (RailCRC) for providing financial support for this research. The authors would also like to thank technical officers Mr Alan Grant and Mr Bob Rowlan for their laboratory assistance.

\section{APPENDIX}

Esveld's method to calculate vertical stress on ballast

Esveld (2001) proposed the following expression to estimate vertical stress on ballast based on Zimmermann's theory

$$
\begin{aligned}
& \sigma_{\text {max }}=\sigma_{\text {mean }}(1+t \bar{s}) \leqslant \bar{\sigma} \\
& \sigma_{\text {mean }}=\frac{Q a}{2 L A}
\end{aligned}
$$

where $\sigma_{\max }$ is the maximum compressive stress exerted on the ballast bed $\left(\mathrm{N} / \mathrm{mm}^{2}\right) ; \sigma_{\text {mean }}$ is the mean value of compressive stress exerted on the ballast bed $\left(\mathrm{N} / \mathrm{mm}^{2}\right) ; Q$ is the effective wheel load $(\mathrm{N})$; $a$ is the sleeper spacing $(\mathrm{m}) ; L$ is the characteristic length $(\mathrm{m}) ; A$ is the contact area between sleeper and ballast bed for half sleeper $\left(\mathrm{m}^{2}\right) ; t$ is the increment factor; $\bar{s}$ is the variation coefficients; and $\bar{\sigma}$ is the permissible stress on the ballast bed directly beneath the sleeper.

Effective wheel load $(Q)$, characteristic length $(L)$ and velocity factor $(\phi)$ are given by the following expressions

$$
\begin{aligned}
Q & =k_{1} Q_{\mathrm{o}} \\
L & =\sqrt[4]{\frac{4 E I}{k_{2}}} \\
k_{2} & =\frac{C A}{a} \\
\phi & =1+\frac{V-60}{140} \quad \text { for } V>60 \mathrm{~km} / \mathrm{h}
\end{aligned}
$$

where $Q_{0}$ is the nominal wheel load $(\mathrm{N}) ; k_{1}$ is $1.1-1 \cdot 3$ and takes account of increase in wheel load in curves because of cant deficiency or excess; $k_{2}$ is the foundation coefficient $\left(\mathrm{N} / \mathrm{m}^{2}\right) ; C$ is the foundation modulus $\left(\mathrm{N} / \mathrm{m}^{3}\right) ; E$ is the modulus of elasticity of steel rail $\left(\mathrm{N} / \mathrm{m}^{2}\right) ; I$ is the moment of inertia of steel rail $\left(\mathrm{m}^{4}\right)$; and $V$ is the train velocity $(\mathrm{km} / \mathrm{h})$.

\section{NOTATION}

$A$ contact area between sleeper and ballast bed for half sleeper $\left(\mathrm{m}^{2}\right)$

$a$ sleeper spacing $(\mathrm{m})$

$a, b$ empirical material constants

$C$ foundation modulus $\left(\mathrm{N} / \mathrm{m}^{3}\right)$

$E$ modulus of elasticity of steel rail $\left(\mathrm{N} / \mathrm{m}^{2}\right)$

$f$ frequency of cyclic loading

I moment of inertia of steel rail $\left(\mathrm{m}^{4}\right)$

$k_{1} 1 \cdot 1-1 \cdot 3$, accounts for increase in wheel load in curves because of cant deficiency or excess

$k_{2}$ foundation coefficient $\left(\mathrm{N} / \mathrm{m}^{2}\right)$

$L$ characteristic length (m)

$M_{\mathrm{r}}$ resilient modulus 


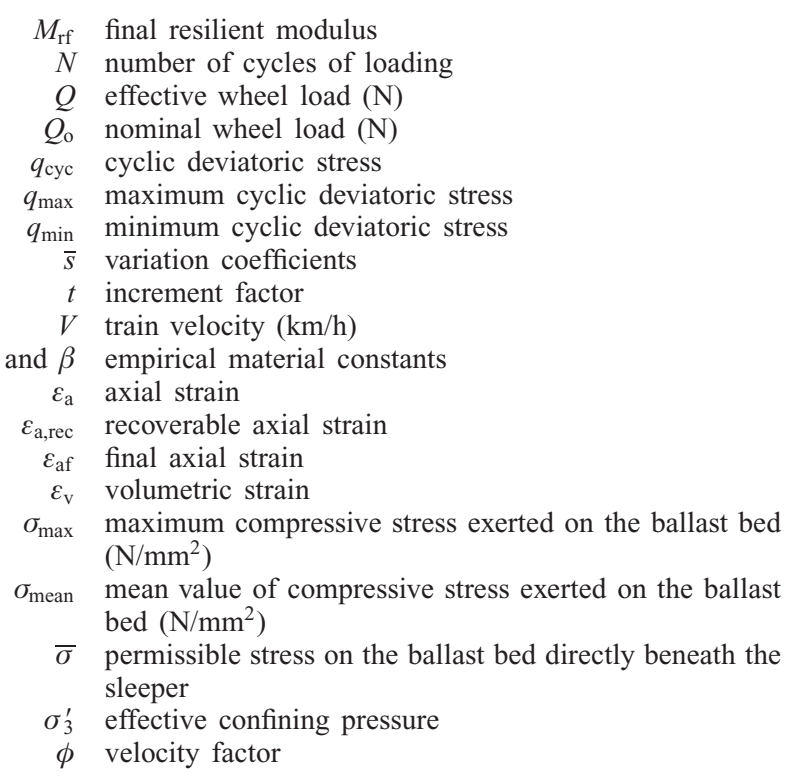

\section{REFERENCES}

ASTM (2002). Standard test method for consolidated undrained triaxial compression test for cohesive soils, pp. 923-935. West Conshohocken, PA, USA: ASTM International.

Esveld, C. (2001). Modern railway track. Zaltbommel, the Netherlands: MRT Productions.

Indraratna, B., Thakur, P. K. \& Vinod, J. S. (2010). Experimental and numerical study of railway ballast behaviour under cyclic loading. Int J. Geomech., ASCE 10, No. 4, 136-144.

Indraratna, B., Lackenby, J. \& Christie, D. (2005). Effect of confining pressure on the degradation of ballast under cyclic loading. Géotechnique 55, No. 4, 325-328, http://dx.doi.org/10.1680/ geot.2005.55.4.325.

Indraratna, B., Vinod, J. S. \& Lackenby, J. (2009). Influence of particle breakage on the resilient modulus of railway ballast. Géotechnique 59, No.7, 643-646, http://dx.doi.org/10.1680/ geot.2008.T.005.

Kempfert, H. G. \& Hu, Y. (1999). Numerical modelling of the deformation in railway foundation - A case study. Proc. 7th Int. Symp. Numer. Models Geomech., Graz, 669-674.

Lackenby, J., Indraratna, B., McDowell, G. \& Christie, D. (2007). Effect of confining pressure on ballast degradation and deformation under cyclic triaxial loading. Géotechnique 57, No. 6, 527536, http://dx.doi.org/10.1680/geot.2007.57.6.527.

Lekarp, F., Isacsson, U. \& Dawson, A. (2000). State of the art. I: resilient response of unbound aggregates. J. Transpn Engng $A S C E$ 126, No. 1, 66-75.

Selig, E. T. \& Alva-Hurtado, J. E. (1982). Predicting effects of repeated wheel loading on track settlement. Proc. 2nd Int. Heavy Haul Railway Conf., Colorado Springs, 476-487.

Selig, E. T. \& Waters, J. M. (1994). Track geotechnology and substructure management. London, UK: Thomas Telford.

Shenton, M. J. (1975). Deformation of railway ballast under repeated loading conditions. In Railroad track mechanics and technology (ed. A. D. Kerr), pp. 387-404. Princeton, NJ, USA: Princeton University.

Standards Australia (1996). Aggregates and rock for engineering purposes, AS 2758.7-1996. Sydney, NSW, Australia: Standards Australia. 